\title{
The New International Division of Labor And Manufacturing Decentralization in the United States\#
}

\author{
NILES HANSEN*
}

The data in Table 1 indicate that manufacturing employment in the United States declined by 2.8 percent between 1970 and 1977. However, the aggregate picture masks substantial differences both among and within regions. Essentially, manufacturing activity has been shifting from the Northeast and North Central regions of the country to the South and West, and from large metropolitan areas to smaller cities and rural areas. Metropolitan areas in the combined Northeast and North Central regions-roughly the traditional industrial heartland-lost 1,237,000 manufacturing jobs while the nonmetropolitan South was gaining 377,000, an increase of 16.6 percent. Manufacturing employment in the West rose by 30.2 percent, though the absolute increase of 100,000 jobs was much less than the corresponding southern increase. These trends are quite consistent with the "filtering down" theory of industrial location, which maintains that:

In national perspective, industries filter down through the system of cities, from places of greater to lesser industrial sophistication. Most often, the highest skills are needed in the difficult, early stage of mastering a new process, and skill requirements decline steadily as the production process is rationalized and routinized with experience. As the industry slides down the learning curve, the high wage rates of the more industrially sophisticated innovating areas become superfluous. The aging industry seeks out industrial backwaters where the cheaper labor is now up to the lesser demands of the simplified process (Thompson, 1969 , p. 8).

The concept of spatial-industrial filtering is closely related to the notion of a product life cycle, which may be regarded somewhat arbitrarily as having three phases: early, growth, and mature (Erickson and

\#Research for this paper was made possible by the Mexico-United States Border Research Program and a grant from the Andrew W. Mellon Foundation. The paper was presented as the Presidential Address at the Annual Meeting of the Southern Regional Science Association, April 1980, Savannah, Georgia.

*Department of Economics, University of Texas, Austin, TX 78712 
TABLE 1. ABSOLUTE AND PERCENTAGE CHANGE IN U.S. MANUFACTURING EMPLOYMENT BY REGION ${ }^{a}$ AND METROPOLITANNONMETROPOLITAN STATUS ${ }^{\mathrm{b}}, 1970-1977$

\begin{tabular}{|c|c|c|c|c|c|c|c|c|c|c|}
\hline & \multicolumn{2}{|c|}{ U.S. } & \multicolumn{2}{|c|}{ Northeast } & \multicolumn{2}{|c|}{ North Central } & \multicolumn{2}{|c|}{ South } & \multicolumn{2}{|c|}{ West } \\
\hline & $\begin{array}{c}\text { Change } \\
(000)\end{array}$ & Percent & $\begin{array}{c}\text { Change } \\
(000)\end{array}$ & Percent & $\begin{array}{c}\text { Change } \\
(000)\end{array}$ & Percent & $\begin{array}{c}\text { Change } \\
(000)\end{array}$ & Percent & $\begin{array}{c}\text { Change } \\
(000)\end{array}$ & Percent \\
\hline Metropolitan & -1055 & -7.1 & -878 & -17.8 & -359 & -7.4 & 85 & 2.9 & 96 & 4.6 \\
\hline Nonmetropolitan & 487 & 9.4 & -48 & -5.3 & 60 & 3.6 & 377 & 16.6 & 100 & 30.2 \\
\hline Total & -568 & -2.8 & -926 & -15.9 & -299 & -4.6 & 462 & 8.8 & 196 & 8.1 \\
\hline
\end{tabular}

${ }^{a}$ the regions are those defined by the U.S. Bureau of the Census

${ }^{b}$ metropolitan status as of January 1, 1978

Source: Computed from Bureau of Labor Statistics and Employment Service data by Claude Haren, Economics, Statistics and Cooperative Service, U.S. Department of Agriculture. 
Leinbach, 1979; Hirsch, 1967). In the early phase, scientific and engineering skills are the critical human input. Because of the relatively short production runs associated with a changing technology, capital outlays are relatively low. Producers depend instead on external economies and subcontracting. In the growth phase, the capitallabor ratio is increased by the introduction of mass production techniques. Competition from other firms forces price cuts; some firms in the industry go out of business while others may merge or vertically integrate their operations. Management skills are vital in this phase. Finally, in the mature phase there is little technological innovation; the product is manufactured in long, routine production runs. Cheap, lowskill labor becomes the key human input; but capital intensity remains relatively high because large amounts of specialized equipment are used. In order to remain competitive, corporations respond to changing input needs-corresponding to differing phases of the product cycle-by changing the geographic location of production. Thus, if this interpretation is correct, corporations would increasingly manufacture multiple products in multiple branch plants in multiple locations.

\section{INDUSTRIAL ORGANIZATION AND DECENTRALIZATION}

A great deal of recent research on manufacturing decentralization appears to cast doubt on the mechanism just outlined. In contrast, it is suggested that recent manufacturing growth in the South (and West) has been a relatively autonomous phenomenon, generated intraregionally by local entrepreneurship. Beyers, for example, finds that those manufacturing activities that expanded rapidly nationally between 1965 and 1975 tended to be those located in the South and West, "possibly suggesting that the technologies of these industries are 'new' and not represented strongly in components of the same industries in the Northeast" (Beyers, 1979, p. 43). Nevertheless, he does acknowledge that "many establishments in these industries may be subsidiaries of corporations headquartered in the Northeast" (Ibid., p. 40).

Rees, while emphasizing the importance of the product cycle in U.S. manufacturing decentralization (Norton and Rees, 1979), maintains that the primary cause of increasing manufacturing employment in the South has been the expansion of existing firms and the birth of new ones (Rees, 1978). Rees (1979, p. 49) further argues that regions that have attracted industry during the standardization phase of the product cycle can evolve as seedbeds of innovation, through either the spin-off of small firms from large firms or the migration of entrepreneurs. These phenomena appear to be particularly evident in Dallas and Houston. There can by now be little doubt that the relative position of some southern SMSAs has improved with respect to research and development activities, yet more general evidence indicates that "The deconcentration of $\mathrm{R}$ and $\mathrm{D}$ from some of the major technological regions is difficult to extrapolate into more general 
trends. Many of the faster-growing areas of $\mathrm{R}$ and $\mathrm{D}$ activity are located in the Northeast despite signs of economic decline in other regional indicators" (Malecki, 1979, p. 321).

A great deal of publicity has been given recently to Dun and Bradstreet data that seem to demonstrate that the decentralization of manufacturing has been a consequence of the birth of new firms or the expansion of existing firms; much is made of the finding that firm relocations are negligible (Allaman and Birch, 1975; Jusenius and Ledebur, 1978). My current research on manufacturing employment change in the Southwest shows that at least in this case Dun and Bradstreet data are highly inaccurate. But even if they were reasonably accurate for the United States as a whole, the assertion that the difference between growing and declining areas is due almost entirely to the rate at which lost jobs are replaced by new firms and the expansion of existing ones ignores the question of branch plants. The principal difficulty arises from the fact that Dun and Bradstreet data records do not include the year of initial operation of branch plants. Without the start date it is not possible to know whether or not a branch was opened during any given time period. Because most branch plants were probably in operation at the beginning of any specified study period, all branch plants could be assumed to be "old" operations for the sake of avoiding upward biases in new employment estimates. But such a procedure clearly involves a downward bias in branch plant starts (Miller, 1979, p. 5). More generally, the notion that firm births, deaths, and relocations can be accurately recorded with ease reveals a naive view of the corporate world.

"Births" and deaths" drawn from Dun and Bradstreet entries give little or no indication of the underlying behavioral and organizational processes involved and imply an independence between actions which may in fact not exist. Such processes may be interrelated in complex, interregional ways, involving indirect ownership patterns, hidden conglomerations, investment policies of major banks, pension funds and other organizations which make the concept of "local" ownership or control a rather tenuous proposition (Krumme, 1979, p. 15).

Malecki finds that even in the South, $\mathrm{R}$ and $\mathrm{D}$ is "a very markedly large-city activity" (Malecki, 1979, p. 321); Rees' studies of technological innovation in the South also are consistent with this observation. How, then, can supporters of the "new entrant" hypothesis account for the fact that fully 82 percent of southern manufacturing employment growth between 1970 and 1977 took place in nonmetropolitan areas? Moreover, much of this growth has been led by such capital intensive industries as paper products and chemicals; even the southern textile industry, where wages are quite low, has relatively high capital-labor ratios. Persky (1978), who also attributes the growth of capital-intensive manufacturing in the South to new entrants (he does not explicitly consider branch plants), is at a loss to ex- 
plain this dualism, which is at odds with neoclassical theory. The resolution of the dilemma lies in the product-cycle and spatialindustrial filtering process, which, as pointed out earlier, suggests that as technology matures there will be decreasing skill intensity and increasing capital intensity, with a locational shift from skill-rich areas to areas with low wage rates. Nelson and Norman (1977) have developed a dynamic comparative advantage model (at odds with neoclassical theory) to explain this phenomenon in terms of international trade shifts, but it applies as well to interregional trade shifts. Moreover, empirical evidence shows that branch plants "are clearly the mechanism through which industrial growth is taking place" in nonmetropolitan areas (Erickson, 1978, p. 17; see also Erickson and Leinbach, 1979).

Those branch plants closest to the main factory are not only smaller, but they typically are rather dependent, requiring constant managerial attention and often maintaining direct flows of materials with the main plant.

More distant branch plants are not only larger, but also are more self-contained in management capability and functionally independent from the main plant and corporate headquarters, manufacturing standardized products whose specifications and technology have reached a stage where they need little change (Erickson, 1978, p. 19).

Similarly, evidence from France indicates that manufacturing decentralization primarily involves capital intensive branch plants employing unskilled or low-skilled labor. Production processes are becoming more heterogeneous and specialized but within individual plants the work performed by individuals is becoming more homogeneous. Manufacturing activities have greatly decentralized from the Paris region in recent years, in keeping with government policy and incentive measures. But a 1975 survey showed that of 788 decentralization operations in question, only 30 were influenced by government subsidies. Non-aided areas have attracted most of the plants and workers in these plants nearly always come from "the privileged reservoir of unskilled labor: women, rural residents, immigrants and young people" (Aydalot, 1978, p. 251).

Finally, there is the question of the origins of the capital required for decentralized activities in the mature phase of the product cycle. Branch plants can be financed out of corporate retained earnings or on the basis of the relatively easy access that larger corporations have to credit markets. While it is true that large $\mathrm{R}$ and $\mathrm{D}$ facilities are no longer a prerequisite for innovations in a wide variety of new industries, it remains to be explained how new entrants would acquire the capital for large production facilities. Moreover, by the time a successful innovation by a new firm reaches the mature phase, the firm probably could not be regarded as a new entrant. Thus, without denying that a great variety of situations exist with respect to industrial organization and manufacturing decentralization, the available 
evidence suggests that branch plants of existing corporations are the typical means by which this process is realized.

\section{THE NEW INTERNATIONAL DIVISION OF LABOR}

In the past, third world countries tended to be regarded as sources of raw materials for Western factories as well as markets for Westernproduced goods. However, it has been argued that in the world of the multinational corporation a new international division of labor has been evolving. It is basically a major geographic extension of locational factors that have already been at work within the United States and other Western countries: the decomposition of complex production processes, better transportation technology, improved telecommunications systems, and, of course, cheap labor. Under these conditions, U.S. corporations have established profitable manufacturing plants in such distant places as Taiwan, South Korea and Hong Kong; and over 100,000 workers are employed just over the border in Mexico in U.S. owned assembly plants that produce exclusively for the U.S. market. This international decentralization has been blamed for the absolute decline of manufacturing employment in the United States.

Looking to the future, it may be asked whether manufacturing decentralization abroad may not have the same consequences for industrial employment in the South as decentralization to the South had for manufacturing employment in the old U.S. industrial heartland. There seems to be remarkably little discussion of this issue; if anything, one usually gets the clear impression that the South is competing quite successfully in the international sphere. The Director of the Southern Growth Policies Board has stated that "Much of the growth in the South during this decade can be attributed to the export sector. Without it, the term Sunbelt would not have the connotations of growth and success that it enjoys" (Southern Growth Policies Board, 1979, p. 1). The Board also points out that manufacturing is the largest component of the export market (SGPB, 1979, p. 3). However, the data presented in Table 2 clearly indicate that export-related manufacturing activities in the South lag well behind those in the United States as a whole. The South, as defined here, includes the 16 states in the South Census Division. For the United States as a whole, export shipments accounted for 7.0 percent of the total value of all manufacturing shipments in 1976. Among the southern states, this figure was reached or exceeded only by Florida and Virginia. Exportrelated employment as a proportion of total manufacturing employment was 6.3 percent in the United States in 1976. The only southern state to reach or exceed this figure was Texas.

These findings need to be interpreted in the light of manufacturing change and structure in the South. As with many other economic and social indicators, changes in the South are decidely favorable, but in comparative static terms the South still lags behind the rest of the country. 
TABLE 2. EXPORTS AND EXPORT-RELATED EMPLOYMENT OF MANUFACTURING ESTABLISHMENTS, UNITED STATES AND STATES IN THE SOUTH CENSUS DIVISION, 1976

\begin{tabular}{|c|c|c|c|c|c|c|}
\hline & \multicolumn{3}{|c|}{$\begin{array}{l}\text { Value of Shipments } \\
\text { (million dollars) }\end{array}$} & \multicolumn{3}{|c|}{$\begin{array}{l}\text { Employment } \\
\text { (thousands) }\end{array}$} \\
\hline & $\begin{array}{c}(1) \\
\text { Total }\end{array}$ & $\begin{array}{c}(2) \\
\text { For } \\
\text { Export }\end{array}$ & $\begin{array}{c}(3) \\
(2) \div(1)\end{array}$ & $\begin{array}{c}(4) \\
\text { Total }\end{array}$ & $\begin{array}{l}\quad(5) \\
\text { Export } \\
\text { Related }\end{array}$ & $\begin{array}{c}(6) \\
(5) \div(4)\end{array}$ \\
\hline U.S. & $\$ 1,185,695$ & $\$ 83,098$ & $7.0 \%$ & 18,753 & 1,173 & $6.3 \%$ \\
\hline Alabama & 17,988 & 832 & 4.6 & 330 & 13 & 3.9 \\
\hline Arkansas & 10,605 & 651 & 6.1 & 188 & 7 & 3.7 \\
\hline Delaware & 5,043 & 188 & 3.7 & 66 & 2 & 3.0 \\
\hline Florida & 18,091 & 1,363 & 7.5 & 331 & 20 & 6.0 \\
\hline Georgia & 28,391 & 1,364 & 4.8 & 469 & 21 & 4.5 \\
\hline Kentucky & 20,269 & 1,137 & 5.6 & 277 & 12 & 4.3 \\
\hline Louisiana & 25,225 & 1,383 & 5.5 & 190 & 9 & 4.7 \\
\hline Maryland & 14,762 & 641 & 4.3 & 243 & 11 & 4.5 \\
\hline Mississippi & 10,868 & 698 & 6.4 & 210 & 10 & 4.8 \\
\hline N. Carolina & 35,819 & 2,202 & 6.1 & 739 & 32 & 4.3 \\
\hline Oklahoma & 10,126 & 579 & 5.7 & 150 & 9 & 6.0 \\
\hline S. Carolina & 16,610 & 935 & 5.6 & 371 & 16 & 4.3 \\
\hline Tennessee & 24,756 & 1,253 & 5.1 & 479 & 19 & 4.0 \\
\hline Texas & 77,120 & 5,201 & 6.7 & 825 & 59 & 7.2 \\
\hline Virginia & 20,471 & 1,545 & 7.5 & 375 & 21 & 5.6 \\
\hline W. Virginia & 7,938 & 447 & 5.6 & 120 & 5 & 4.2 \\
\hline
\end{tabular}

Source: U.S. Bureau of the Census, Statistical Abstract of the United States: 1979 (Washington, D.C.: U.S. Government Printing Office, 1979), p. 812.

Between 1972 and 1977, employment in predominantly laborintensive, low-wage southern manufacturing sectors-textiles, apparel, furniture, lumber and wood, leather, and miscellaneous manufacturing-declined by about 19,000 jobs. New southern manufacturing employment was concentrated in high and medium-wage sectors, especially non-electrical machinery, electrical equipment, rubber and plastics, fabricated metals, and chemicals. In 1977, 39 percent of southern manufacturing employment was in high-wage industries, compared with 36 percent in low-wage industries. But there was considerable variability among southern states. Low-wage sectors accounted for over half of all manufacturing employment in Mississippi and the Carolinas, and for almost half in Arkansas and Georgia. The average annual payroll per manufacturing worker in the South was only 84 percent of the corresponding national average, which means the difference between the South and the rest of the nation was still greater (Brunson, 1980). Thus, despite the upgrading of southern manufacturing, the region still is relatively specialized in low-wage activities, many of which compete with low-wage manufacturing abroad. This may help to explain the fact that southern manufacturing is less export oriented than that in the rest of the United States. 
Despite foreign competition in traditionally low-wage manufacturing sectors, there are reasons for believing that the harbingers of the new international division of labor (many of whom wed this concept to the doctrine of capitalist exploitation of labor) have overstated their case. Between 1970 and 1978, U.S. direct investment abroad increased from $\$ 75.5$ billion to $\$ 168.0$ billion. The share accounted for by manufacturing was 41 percent in each year. U.S. direct investment in manufacturing abroad rose from $\$ 31.0$ in 1970 to $\$ 51.2$ billion in the recession year of 1974 to $\$ 74.2$ billion in 1978 . However, the share of this direct investment in manufacturing accounted for by the developed countries (principally Canada and the European Economic Community) remained virtually the same in each year: 82 percent in 1970 and 1974, and 81 percent in 1978 (Whichard, 1979, p. 24). In other words, the lure of cheap labor in the developing countries remained relatively weak in comparison to the perceived advantages, e.g. proximity to markets, offered by the developed countries.

The temporal-spatial pattern of foreign direct manufacturing investment in the United States also is instructive in this regard. Such investment increased from $\$ 13.3$ billion in 1970 to $\$ 40.8$ billion in 1978 , or by 207 percent. The corresponding rate of increase of direct U.S. manufacturing investment abroad was only 139 percent (U.S. Bureau of the Census, 1979, pp. 851-852). In 1976, the location pattern of foreign-owned manufacturing firms in the United States was strongly oriented toward the traditional manufacturing heartland, reflecting the importance of locational determinants other than cheap labor. However, between 1976 and 1978 the greatest growth of foreign investment was in the South and, especially, in the West. Foreign investment in the heartland and the remainder of the country trailed the average national rate of growth. Thus, foreign corporations are belatedly beginning to follow the decentralization pattern that has already become well-established (McConnell, 1980). But cheap labor does not appear to be a major consideration in this regard. In 1977, the chemicals and related products sector alone accounted for 36 percent of all foreign direct investment in U.S. manufacturing; and the machinery and primary and fabricated metals sectors together accounted for another 31 percent (Fouch and Lupo, 1979, p. 46).

In summary, despite the increasing significance of exports in southern manufacturing, the continuing (though declining) relative importance of low-wage sectors tends to put the South at a disadvantage in international markets, because of decentralization to countries where wages are much lower still. Continuing efforts to upgrade southern manufacturing will be needed if the South is to compete internationally on an equal footing with the rest of the nation, but stiff competition still faces the South within the United States.

Lacking natural resources, New England has relied heavily upon the quality of its human resources to adapt to change and maintain economic progress. Contrary to conventional Sunbelt-Frostbelt wisdom, "one of the ironies of current public policy as viewed from a 
New England perspective is that allocation formulas for public funds and other federal aids for regional economic transitions are becoming more favorable and available to New England just as the worst of its own transition problems may be at an end" (Meyer and Leone, 1978, p. 114). As an example of New England's favorable position, a consultant to German firms seeking to establish operations in the United States recently told me that there has been a relative shift of interest in favor of New England, and especially Massachusetts and Connecticut. The lower wages of the South are more than outweighed by the external economics (business services, transportation) and more highly skilled labor available in New England. While a cheap labor force may be desirable when standardized products are being manufactured, it is a disadvantage when high-technology products must be adapted to the needs of specific users. Despite relatively high wages, innovation has kept New England competitive in international markets. In 1976, the value of manufacturing shipments accounted for by exports exceeded the national average of 7.0 percent in Connecticut (10.7 percent), Vermont (9.7 percent), Massachusetts (9.3 percent), and New Hampshire (8.3 percent). The proportion of manufacturing employment that was export related exceeded the national average of 6.3 percent in Vermont (9.8 percent), Connecticut (9.1 percent), Massachusetts (8.1 percent), and New Hampshire (8.0 percent) (U.S. Bureau of the Census, 1979, p. 812).

California is another high-wage state where the value of manufacturing shipments accounted for by exports (7.9 percent) and the proportion of manufacturing employment that is export related (7.8 percent) exceed the respective national averages (U.S. Bureau of the Census, 1979 , p. 812). California also has some of the world's most respected private and public (particularly university) centers of research and innovation. In 1978, California alone accounted for 19 percent of all new jobs created in the United States. Although only one-fifth of the state's nonfarm work force is employed in manufacturing, California has more manufacturing workers than any other state. The aerospace and electronics industries, which have given particular impetus to California's recent growth, reflect a general phenomenon: the continuing creation of new activities. In contrast to the South, most of the manufacturing activities in California were virtually nonexistent thirty years ago (Immel, 1979, p. 34).

\section{SUMMARY AND CONCLUSLONS}

Between 1970 and 1977, manufacturing employment in the United States declined absolutely. The Northeast and North Central regions together lost 1,225,000 manufacturing jobs, but the South and West together gained 658,000 . Over half of the combined South-West increase was in the nonmetropolitan South, where manufacturing employment rose by 377,000 . It has been argued here that contrary to the assertions of some studies, corporation branch plants have been the major vehicle for industrial decentralization. Moreover, the decen- 
tralization process, especially insofar as it involved relatively cheap southern labor, can be explained in terms of the related product cycle and spatial-industrial filtering hypotheses, which also provide a plausible explanation for the decentralization of many labor-intensive manufacturing activities abroad. Despite the relatively rapid growth of higher-wage manufacturing sectors in the South, the continuing dominance of low-wage sectors has placed the region at a disadvantage in international markets, because of competition from countries where wages are still lower. Although U.S. direct manufacturing investment abroad heavily favors developed countries, the amount of such investment in the developing countries increased from $\$ 5.5$ billion in 1970 to $\$ 14.1$ in 1978. Moreover, the process by which southern manufacturing has grown by attracting increasing shares of nationally-declining industries cannot be expected to continue indefinitely. Thus, on both international and domestic grounds, it is unlikely that there will be substantial future gains in southern low-wage manufacturing employment.

The South has been making significant progress with respect to the growth of relatively high-wage industries, but it still lags behind such areas as New England and California in ability to innovate new highwage activities. In other words, the South faces stiff competition at both the low and high ends of the manufacturing wage spectrum. Assuming there is little enthusiasm for pursuing a low-wage future, the South can continue to make reasonable advances in the middle range or it can attempt to complete at the higher end. However, I would agree with Lasuen that efforts to create research and educational magnets on the model of Stanford-Berkeley and Harvard-MIT, together with their proximate spin-off activities, would be a mistake "because the duplication of those magnets is simply not feasible" (Lasuen, 1972, p. 40). Nor would it be wise to resort to tax gimmicks and other financial inducements to lure advanced-technology industries. Some parties already have replaced the admittedly inaccurate Frostbelt vs. Sunbelt syndrome with a Taxbelt vs. Growthbelt view of the nation. In fact, the relative unimportance of taxes in industrial location decisions has been documented by at least five major recent studies (Pluta, 1980). One could go on about the importance of transportation, proximity to markets and suppliers, energy costs, and other factors that affect industrial location. But I believe the fundamental issue lies elsewhere. A few years ago, the late Frederick Harbison remarked that:

Capital and natural resources are passive factors of production; human beings are the active agents who accumulate capital, exploit natural resources, build social, economic, and political organizations, and carry forward national development. Clearly, a country which is unable to develop the skills and knowledge of its people and to utilize them effectively in the national economy will be unable to develop anything else (Harbison, 1973, p. 3). 
In this regard, what is true of nations is true of regions. And compared to the past, the South recently has made significant strides in human resource development. Yet the region still ranks worst in terms of any objective measurers of health, poverty and education. Whether in a national or international context, the future of the South will be tied to its success in addressing these deficiencies.

\section{REFERENCES}

1. Allaman, Peter M. and David L. Birch, "Components of Employment Change for Metropolitan and Rural Areas in the United States by Industry Group, 1970-1972," (Cambridge, Mass.: WP-8, Interarea Migration Project, MIT-Harvard Joint Center for Urban Studies, 1975).

2. Aydalot, Philippe, "L'aménagement du territoire en France: une tentative de bilan," L'Espace Géographique 7, no. 4 (October 1978), pp. 245-253.

3. Beyers, William. "Contemporary Trends in the Regional Economic Development of the United States," The Professional Geographer 31, no. 1 (February 1979), pp. 34-44.

4. Brunson, E. Evan. "Manufacturing Trends in the Southern States: 1972 to 1977," research memorandum (Research Triangle Park, N.C.: Southern Growth Policies Board, May 23, 1980).

5. Erickson, Rodney A., "The New Wave of Nonmetropolitan Industrialization," Earth and Mineral Sciences 48, no. 3 (December 1978), pp. 17-20.

6. Erickson, Rodney and Thomas R. Leinbach, "Characteristics of Branch Plants Attracted to Nonmetropolitan Areas," in Richard E. Lonsdale and H. L. Seyler, eds., Nonmetropolitan Industrialization (New York: Halsted Press, 1979), pp. 57-78.

7. Fouch, Gregory, and L. A. Lupo, "Foreign Direct Investment in the United States in 1978," Survey of Current Business 59, no. 8 (August 1979), pp. 38-51.

8. Harbison, Frederick H., Human Resources as the Wealth of Nations (London: Oxford University Press, 1973).

9. Hirsch, Werner. Location of Industry and International Competitiveness (Oxford: Clarendon Press, 1967).

10. Immel, Richard A., "California and Other States in the Sun Belt Seem Likely to Weather a Recession Well," Wall Street Journal, August 15, 1979.

11. Jusenius, Carol L., and Larry C. Ledebur, Documenting the "Decline" of the North (Washington, D.C.: Economic Development Administration, U.S. Department of Commerce, 1979).

12. Krumme, Günter, "Corporate Organization and Regional Development in the American Federal System," Paper presented to the German-American Seminar on The Impact of the Federal System on Regional Development, Austin, Texas, September 29, 1979.

13. Lasuen, J. R., "On Growth Poles," in Niles Hansen, ed., Growth Centers in Regional Economic Development
(New York: The Free Press, 1972).

14. Malecki, Edward J., "Location Trends in R and D by Large U.S. Corporations, 1965-1977," Economic Geography 55, no. 4 (October 1979), pp. 309-323.

15. McConnell, James E., "Foreign Direct Investment in the U.S.," Annals of the Association of American Geographers 70, no. 2 (June 1980), forthcoming.

16. Meyer, John R., and Robert A. Leone, "The New England States and their Economic Future," American Economic Review 68, no. 2 (May 1978), pp. 110-115.

17. Miller, James P., "Research with Dun and Bradstreet Data," Working Paper No. 7903 (Washington, D.C.: Economic Development Division, U.S. Department of Agriculture, 1979).

18. Nelson, Richard R. and Victor D. Norman, "Technological Change and Factor Mix over the Product Cycle," Journal of Development Economics 4, no. 1 (1977), pp. 3-24.

19. Norton, R. D. and J. Rees, "The Product Cycle and the Spatial Decentralization of American Manufacturing," Regional Studies 13, no. 2 (1979), pp. 141-151.

20. Persky, Joseph, "Dualism, Capital-Labor Ratios and the Regions of the U.S.," Journal of Regional Science 18, no. 3 (December 1978), pp. 373-382.

21. Pluta, Joseph E., "Taxes and Industrial Location," Texas Business Review 54, no. 1 (January-February 1980), pp. 1-6.

22. Rees, John, "Manufacturing Change, Internal Control and Government Spending in a Growth Region of the USA," in F.E.I. Hamilton, ed., Industrial Change: International Experience and Public Policy (London: Longman, 1978), pp. 155-174.

23. Rees, John, "Technological Change and Regional Shifts in American Manufacturing," The Professional Geographer 31, no. 1 (February 1979), pp. 45-54.

24. Southern Growth Policies Board, "Southern Export Boom," Southern Growth: Problems and Promise, 7, no. 2 (Fall 1979).

25. Thompson, Wilbur R. "The Economic Base of Urban Problems," in Neil W. Chamberlain, ed., Contemporary Economic Issues (Homewood, Ill.: Richard D. Irwin, 1969), pp. 1-47.

26. Whichard, Obie G., "U.S. Direct Investment Abroad in 1978," Survey of Current Business, 59, no. 8 (August 1979), pp. 15-37. 